\title{
Association between Luteinizing Hormone/Choriogonadotropin Receptor Ins18LQ Gene Polymorphism and Polycystic Ovary Syndrome
}

Hilma Putri Lubis*, Muhammad Fidel Ganis Siregar, Ichwanul Adenin, Binarwan Halim, Henry Salim Siregar, M. Oky Prabudi

Department of Obstetrics and Gynecology, Division of Reproductive Endocrinology and Infertility, Faculty of Medicine, Universitas Sumatera Utara, Medan, Indonesia

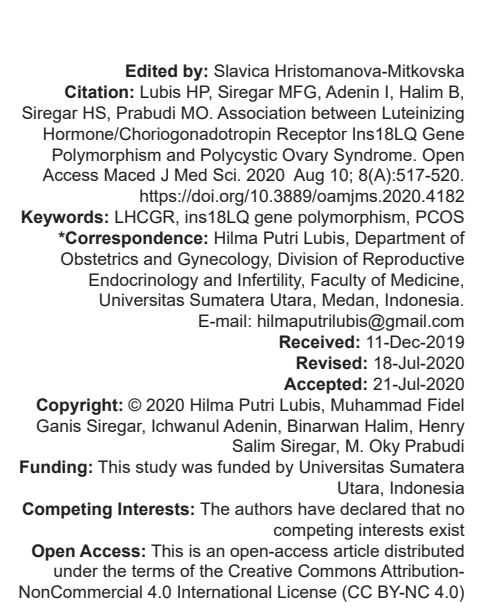

\begin{abstract}
BACKGROUND: Polycystic ovary syndrome (PCOS) is one of the most common endocrine disorders of women in the childbearing period. However, its pathophysiology is still unclear. Certain polymorphisms of the luteinizing hormone/choriogonadotropin receptor (LHCGR) genes may lead to changes in the bioactivity of this hormone. The important functional role of LHCGR in the metabolism of androgen and ovulation, the LHCGR gene variant, may be related to the risk of PCOS.

AIM: The aim of this study was to evaluate the association between LHCGR Ins18LQ gene polymorphism and PCOS.

METHODS: A case-control study was performed in women with PCOS and non-PCOS from May 2019 to October 2019 in HFC IVF Center. We included 50 women with PCOS and 50 healthy controls. Polymorphism of the LHCGR (ins18LQ) gene was genotyped using polymerase chain reaction-restriction fragment length polymorphism.

RESULTS: From this study, we found that there was no significant difference in the proportion of ages between the groups $(p>0.05)$. There were significant differences in the characteristics of body mass index, FSH level, LH level, and LH/FSH ratio between the PCOS and control groups $(p<0.05)$. We also found that the proportion of heterozygote variant non-ins/ins was higher in the PCOS group compared to the control group, but there was no significant difference between the polymorphisms of the non-ins and non-nonins variants between the PCOS and control groups $(p=0.269)$. The frequency of ins alleles was higher in the PCOS group compared to the control group. CONCLUSION: There was no significant association between LHCGR ins18LQ gene polymorphism and PCOS.
\end{abstract}

\section{Introduction}

Polycystic ovary syndrome (PCOS) is one of the most common ovulatory disorders, affecting $5-10 \%$ of women of reproductive age. This is characterized by the failure of the ovaries, polycystic ovaries, and excess production of androgens, which can cause infertility [1], [2]. Nowadays, the etiology of PCOS is still unclear. Some due to genetic and hormonal factors affecting the pathogenesis of PCOS include alteration of ovarian steroid synthesis, hyperinsulinemia, impaired folliculogenesis, abnormalities in gonadotropin, and neuroendocrine secretions [3], [4], [5].

Some studies showed that genetic factors are very important in the development of PCOS. The study on genes susceptible to PCOS has focused mainly on gene polymorphisms that encode sex hormones and regulatory proteins such as folliclestimulating hormone $ß$, follicle-stimulating hormone receptor, luteinizing hormone/choriogonadotropin receptor (LHCGR), estrogen receptor alphareceptor (ESR1), and estrogen receptor ß (ESR2). Variants of genetic markers have implications for the predisposition of PCOS; however, there are no variants that are directly and repeatedly linked to PCOS [3], [6].

Several single nucleotide polymorphisms can change the expression of genes or the function of the LHCGR protein, which has been identified in the LHCGR gene. Given the important functional role of LHCGR in androgen metabolism and ovulation, the LHCGR gene variant may be associated with the risk of PCOS [3], [6], [7], [8].

Chen et al. conducting a genome-wide association study SOPK in Han Chinese women found evidence of a strong association between PCOS and the LHR gene locus [9].

The aim of this study was to evaluate the association between LHCGR Ins18LQ gene polymorphism and PCOS. 


\section{Materials and Methods}

This case-control study included 100 unrelated women: 50 women with PCOS and 50 healthy women with regular menses and ultrasonographically normal ovaries from May 2019 to October 2019 in Halim Fertility Center, Division of Reproductive Endocrinology and Infertility, Department of Obstetrics and Gynecology, Faculty of Medicine, Universitas Sumatera Utara, Haji Adam Malik General Hospital, Medan, Indonesia. The diagnosis of PCOS was based on the 2004 revised Rotterdam criteria (24). At least two of the following three features needed to be present: (1) Oligo-ovulation or anovulation ( $<6$ menstrual periods per year); (2) clinical and/or biochemical signs of hyperandrogenism, including hirsutism (Ferriman-Gallwey score $>8$ ) and/or total testosterone level $>0.8 \mathrm{ng} / \mathrm{mL}$; and (3) sonographic evidence of PCOS. Other causes of oligomenorrhea were excluded in patients with PCOS.

All women underwent a complete history, including cycle length and a thorough clinical examination. All women were not in pregnancy and did not use oral contraception in the last 3 months. We assessed clinical and anthropometrical variables, including body mass index (BMI) in all participants. Exclusion criteria for all women included a history of hyperandrogenic states (such as non-classic congenital adrenal hyperplasia, androgen-secreting tumors, Cushing's syndrome, 21-hydroxylase deficiency, or hyperprolactinemia), diabetes mellitus, hypertension, liver, kidney, or thyroid diseases.

\section{Biochemical measurements}

Blood samples were drawn from all subjects during the early follicular phase of the menstrual cycles. We took that blood sample $3 \mathrm{cc}$ of whole blood was collected into tubes containing EDTA for determination of DNA isolation.

\section{DNA extraction}

Genomic DNA was extracted from EDTA whole blood using a spin-column method according to the protocol (Promega). DNA was stored at $-20^{\circ} \mathrm{C}$ till the time of use.

\section{Genotyping of LHCGR genes polymorphisms}

Genotyping for the ins18LQ (rs4539842) in exon one genes polymorphisms was performed by a polymerase chain reaction-restriction fragment length polymorphism method. The PCR protocols of LHCGR ins $18 \mathrm{LQ}$ were performed with the following settings: $94^{\circ} \mathrm{C}$ for $5 \mathrm{~min}$, followed by 35 cycles at $94^{\circ} \mathrm{C}$ for $30 \mathrm{~s}$, $56^{\circ} \mathrm{C}$ of LHCGR ins $18 \mathrm{LQ}$ for $30 \mathrm{~s}$, and $72^{\circ} \mathrm{C}$ for $45 \mathrm{~s}$.
A final extension step was carried out at $72^{\circ} \mathrm{C}$ for $7 \mathrm{~min}$. All PCR products were digested with restriction enzymes according to the manufacturer's instruction. The fragments were resolved by gel electrophoresis in a $2 \%$ agarose gel stained with ethidium bromide $1.0 \mu \mathrm{L}$ and visualized under a UV transilluminator. A 50-bp ladder was used as a marker. PCR primer sequence, restriction enzyme, and fragments size are listed (Table 1). Notably, $10 \%$ of the samples were amplified twice for checking the accuracy of the results.

Table 1: PCR primer sequence, restriction enzyme, and fragment size for the detection of LHCGR gene polymorphism

\begin{tabular}{|c|c|c|c|}
\hline SNP locus & PCR primer sequence & $\begin{array}{l}\text { Restriction } \\
\text { enzyme }\end{array}$ & Fragment Size \\
\hline $\begin{array}{l}\text { LHCGR } \\
\text { ins18LQ }\end{array}$ & $\begin{array}{l}\text { F:5'- } \\
\text { GACACTGGCAAGCCGCAGAAGCCC-3' } \\
\text { R:5'- } \\
\text { GCTGTGTACTCACAGTCGAGTGAG-3' }\end{array}$ & Pvull & $\begin{array}{l}\text { non-ins allele: } 65 \\
+149 \text { bp } \\
\text { ins allele: } \\
65+27+128 \text { bp }\end{array}$ \\
\hline
\end{tabular}

\section{Statistical analysis}

Data were analyzed by computer applications in accordance with comparative analytical data presentation. Data were expressed using descriptive statistics (mean \pm standard deviation) and were analyzed using the test. To analyze the association between LHCGR Ins 18 LQ and PCOS group, we used a one-way analysis of variance test to compare different parameters. $p<0.05$ was considered statistically significant. Genotype frequencies in cases and controls were tested for Hardy-Weinberg equilibrium and any deviation between the observed and expected frequencies were tested for significance. The statistical analysis was performed using SPSS 17.0.

\section{Results}

During the study period, 100 subjects were included in the analysis. The patient demographics, age of women, BMI, FSH level, LH level, and LH/FSH ratio are depicted in Table 2. From Table 2, we found that there was no significant difference between the PCOS group and the control group in the age of women $(p>0.05)$. We also found that BMI in women with

Table 2: Distribution of characteristics of PCOS and control groups

\begin{tabular}{|c|c|c|c|}
\hline \multirow[t]{2}{*}{ Characteristics } & PCOS & Controls & \multirow[t]{2}{*}{$\mathrm{p}$-value } \\
\hline & $n=50$ & $n=50$ & \\
\hline Age (mean \pm SD) & $29.5 \pm 3.6$ & $31.2 \pm 4.24$ & \\
\hline$>30$ yo $(\mathrm{n} \%)$ & $19(38)$ & $29(58)$ & $0.361^{\mathrm{a}}$ \\
\hline$\leq 30$ yo $(n \%)$ & $31(62)$ & $21(42)$ & \\
\hline Body mass index $\left(\mathrm{kg} / \mathrm{m}^{2}\right),($ mean $\pm \mathrm{SD})$ & $26.4 \pm 4.61$ & $24.23 \pm 2.93$ & $0.019^{b}$ \\
\hline Underweight (<18.5) (n\%) & $1(2)$ & $2(4)$ & \\
\hline Normal weight $(18.5-24.9)(\mathrm{n} \%)$ & $21(42)$ & $30(60)$ & \\
\hline Overweight $(25-29.9)(\mathrm{n} \%)$ & $19(38)$ & $16(32)$ & \\
\hline Obese $(\geq 30)(n \%)$ & $9(18)$ & $2(4)$ & \\
\hline $\mathrm{FSH},($ Mean $\pm \mathrm{SD})$ & $5.07 \pm 1.19$ & $5.94 \pm 1.89$ & $0.008^{\mathrm{c}}$ \\
\hline LH, (Mean \pm SD) & $10.97 \pm 8.34$ & $3.63 \pm 1.57$ & $<0.001^{\circ}$ \\
\hline LH/FSH ratio, (Mean \pm SD) & $2.10 \pm 1.16$ & $0.65 \pm 0.31$ & $<0.001^{\circ}$ \\
\hline
\end{tabular}


PCOS was higher than controls ( $p<0.05$ ). FSH level in the PCOS group was lower than the control group, and there was a significant difference between them $(p<0.05)$. We also found that the LH level and LH/FSH ratio in the PCOS group was higher than the control group, and there was a significant difference between them $(p<0.05)$.

From Table 3, the proportion of wild-type nonins/non-ins homozygote genotypes in the PCOS group was lower than the control group with a proportion of $88 \%$ versus $96 \%$. Meanwhile, for the proportion of heterozygote variant non-ins/ins, in the PCOS group, there were six women (12\%), while in the control group, there were only two women $(4 \%)$. No homozygote mutant ins/ins genotypes were found in the two groups. The frequency of non-ins allele in the PCOS group was $94 \%$, lower than the control group with a proportion of $98 \%$. The frequency of ins alleles in the PCOS group was higher than in the control group (6\% vs. $2 \%)$. There was no significant difference in LHCGR ins18LQ gene polymorphism between PCOS and controls ( $p>0.05)$.

\section{Discussion}

PCOS is one of the most common ovulatory disorders, affecting $5-10 \%$ of women of reproductive age [3], [10], [11], [12], [13]. Recently, many studies suggested that genetic factors were strongly associated with the etiology of PCOS [2], [3], [10], [11], [12], [13]. However, only a few genes were found to have an association with PCOS or some clinical traits related to PCOS. Until now, the relationship between the $\mathrm{LH}$ signaling pathway and PCOS has not been defined clearly [3], [11], [12], [13].

From this study, we found that BMI in women with PCOS was higher than women without PCOS and there was a significant difference between them ( $p<0.05)$. Elshal et al. and Gambineri et al. also found that the majority of patients with PCOS had obese BMI $(77.1 \%)$ [3], [14]. The results of this study are also in accordance with the research of Thathapudi et al. which reported that there was a significant difference between BMI in PCOS and controls ( $p<0.05)$, where BMI in PCOS was higher than in controls [8].

In this study, we found that the FSH level in the PCOS group was lower than the control and there was a significant difference between them $(p<0.05)$. Then, we also found that the LH level and LH/FSH ratio

Table 3: The association between LHCGR ins18LQ gene polymorphism and PCOS

\begin{tabular}{llll}
\hline Polymorphism LHCGR ins18LQ & PCOS $\mathrm{n}=50$ & Controls $\mathrm{n}=50$ & $\mathrm{p}$-value \\
\hline Non-ins/non-ins (n\%) & $44(88)$ & $48(96)$ & $0.269^{\mathrm{a}}$ \\
Non-ins/ins (n\%) & $6(12)$ & $2(4)$ & \\
Non-ins allele (n\%) & $94(94)$ & $98(98)$ & $0.279^{\mathrm{a}}$ \\
Ins allele ( $\mathrm{n} \%)$ & $6(6)$ & $2(2)$ & \\
\hline${ }^{\mathrm{a}}$ Fischer's exact. & & &
\end{tabular}

in the PCOS group was higher than the control group, and there was significant difference between them $(p<0.05)$. Similar to our data, Thathapudi et al. also found that $\mathrm{LH}$ level and $\mathrm{LH} / \mathrm{FSH}$ ratio was higher in the PCOS group than control group $(p<0.05)$ [8].

In this study, there was no significant difference in LHCGR Ins18LQ gene polymorphism between PCOS and Control groups with $p>0.05$. In the LHCGR ins 18LQ gene polymorphism, no significant relationship was found between the polymorphisms of the nonins and non-nonins variants between the PCOS and control groups ( $p>0.05$ ). In LHCGR ins18LQ gene polymorphism, the results of this study are in line with research by Elshal et al. and Liu et al., where they did not find a meaningful relationship between LHCGR ins 18LQ polymorphisms with PCOS in Egyptian women and Chines Han [3], [11]. However, this is different from the study by Valkenburg et al. who found that the 18ins LQ insertion allele frequency was significantly lower in Caucasian PCOS women than controls [15].

\section{Conclusion}

There was no significant association between LHCGR ins18LQ gene polymorphism and PCOS.

\section{Acknowledgment}

This study was funded by Universitas Sumatera Utara. The authors thank all the teams and the patients.

\section{References}

1. Speroff L, Fritz AM. Clinical Gynecologic Endocrinology and Infertility: Chronic Anovulation and the Polycystic Ovary Syndrome. $8^{\text {th }}$ ed. North Caroline: Lippincott Williams and Wilkins; 2011. p. 495-531.

2. Bassiouny YA, Rabie WA, Hassan AA, Darwish RK. Association of the luteinizing hormone/choriogonadotropin receptor gene polymorphism with polycystic ovary syndrome. Gynecol Endocrinol. 2014;30(6):428-30. https://doi.org/10.3109/095135 90.2014 .895982

PMid:30182769

3. Elshal AS, Zidan HE, Rashad NM, Abdelaziz AM, Harira MM Association between genes encodingcomponents of the leutinizing hormone/luteinizing hormonechoriogonadotrophinreceptor pathway and polycystic ovary syndrome in Egyptian women. Int Union Biochem Mol Biol. 2015;68(1):23-36. https://doi.org/10.1002/iub.1457 PMid:26662070 
4. Panda PK, Rane R, Ravichandran R, Singh S, Panchal H. Genetics of PCOS: A systematic bioinformatics approach to unveil the proteins responsible for PCOS. Genom Data. 2016;8:52-60. https://doi.org/10.1016/j.gdata.2016.03.008

5. Robeva R, Andonova S, Tomova A, Kumanov P. LHCG receptor polymorphisms in PCOS patients. Biotechnol Biotechnol Equipment. 2018;1:1-6. https://doi.org/10.1080/13102818.2017 .1423246

6. Liaqat I, Jahan N, Krikun G, Taylor HS. Genetic polymorphisms in Pakistani women with polycystic ovary syndrome. Reprod Sci. 2014;22(3):347-57. PMid:25100445

7. Zou J, Wu D, Liu Y, Tan S. Association of luteinizing hormone/ choriogonadotropin receptor gene polymorphisms with polycystic ovary syndrome risk: A meta-analysis. Gynecol Endocrinol. 2019;35(1):81-5. https://doi.org/10.1080/09513590 .2018.1498834

PMid:30182769

8. Thathapudi S, Kodati V, Erukkambattu J, Addepally U, Qurratulain H. Association of luteinizing hormone chorionicgonadotropin receptor gene polymorphism (rs2293275) with polycystic ovarian syndrome. Genet Test Mol Biomarkers. 2015;19(3):128-32. https://doi.org/10.1089/gtmb.2014.0249 PMid:25565299

9. Chen ZJ, Zhao H, He L, Shi Y, Qin Y, Shi, Y, et al. Genomewide association study identifies susceptibility loci for polycystic ovary syndrome on chromosome 2p16.3, 2p21 and 9q33.3. Nat Genet. 2011;43(1):55-9. https://doi.org/10.1038/ng.732 PMid:21151128

10. Ha L, Shi Y, Zhao J, Li T, Chen ZJ. Association study between polycystic ovarian syndrome and the susceptibility genes polymorphisms in Hui Chinese women. PLoS One. 2015;10(5):110. https://doi.org/10.1371/journal.pone. 0126505 PMid:25978310

11. Liu N, Ma Y, Wang S, Zhang X, Zhang Q, Zhang X, Fu L, et al. Association of the genetic variants of luteinizing hormone, luteinizing hormone receptor and polycystic ovary syndrome. Reprod Biol Endocrinol. 2012;10:36. https://doi. org/10.1186/1477-7827-10-36 PMid:22546001

12. Almawi WY, Hubail B, Arekat DZ, Al-Farsi SM, Al-Kindi SK, Arekat MR, et al. Leutinizing hormone/choriogonadotropin receptor and follicle stimulating hormone receptor gene variants in polycystic ovary syndrome. J Assist Reprod Genet. 2015;32(4):607-14. https://doi.org/10.1007/s10815-015-0427-0 PMid:25649397

13. Crespo RP, Bachega TA, Mendonca BB, Gomes LG. An update of genetic basis of PCOS pathogenesis. Arch Endocrinol Metab. 2018;62(3):352-61. https://doi. org/10.20945/2359-3997000000049 PMid:29972435

14. Gambineri A, Pelusi C, Vicennati V, Pagotto U, Pasquali R. Obesity and the polycystic ovary syndrome. Int J Obes Relat Metab Disord. 2002;26(7):883-96. https://doi.org/10.1038/ sj.ijo.0801994

PMid: 12080440

15. Valkenburg O, Steegers-Theunissen RP, Smedts HP, DallingaThie GM, Fauser BC, Westerveld FH, et al. A more atherogenic serum lipoprotein profile is present in women with polycystic ovary syndrome: A case control study. J Clin Endocrinol Metab. 2008;93(2):470-6. https://doi.org/10.1210/jc.2007-1756 PMid:18056772 